Gathiram, $N$

\title{
PARTICIPATION, CIVIL SOCIETY AND SOCIAL WORK PRACTICE
}

\author{
Dr Neeta Gathiram is a Lecturer in the School of Sport Science and Social Work at the University \\ of Durban-Westville
}

\section{INTRODUCTION}

In 1994 South Africa became a democracy with a government elected by the people for the people. Citizens taking control of their own lives is a general goal of a democracy. The Constitution (RSA, 1996), the Reconstruction and Development Programme (ANC, 1994) and subsequent policy documents all advocate the importance of participation and the role of civil society in democratising South Africa. South Africa has chosen the path of developmental social welfare as its reformist approach to explaining and overcoming social problems. Crucial to social change is active citizen participation at many different levels that will enable citizens to contribute to the process of change that will then lead to nation-building, reconciliation and reconstruction (Pretorius-Heuchert \& Ahmed, 2001:32). The government has committed itself to collaborating with non-governmental organisations as representative organs of civil society and its entire people in the reconstruction and development of the country. The year 2002 has been declared the year of the volunteer. The Africa National Congress has also launched its matsema campaign or voluntary community service programme to empower communities.

The challenge facing South Africa today is how to get a politically and economically disenfranchised population involved in civic activities that are truly empowering. Many local, provincial and national government departments are creating structures to give civil society a meaningful role in government processes. It has been legislated in certain instances, for example in public works programmes, that there must be quotas to ensure adequate representation of women on committees. Much effort has been taken to ensure that non-governmental organisations have been representatives of civil society in government policy development and in advisory roles in structures of government.

Developmental interventions require a new way of working in partnerships with communities. This demands that social workers play a variety of roles within the framework of development. This paper will define developmental social welfare and participation. A discussion on the importance of the participation of civil society and its relevance to social work will follow. The paper concludes with implications for social work practice.

Sustaining development programmes in rural areas remains a challenge; factors inhibiting the serving the poorest of poor include the under-development of the voluntary sector in rural areas and in former homelands (Patel, 1998:121). A lack of participation and human resources capacity, amongst other things, has been cited as a problem. It is intended that this article will contribute to this crucial challenge facing social workers and stimulate ideas for future research.

\section{DEVELOPMENTAL SOCIAL WELFARE AND PARTICIPATION}

Staudt (cited by Cowen \& Shenton, 1995:28) defines development as "a process of enlarging people's choices, of enhancing participatory democratic processes and the ability of people to have a say in the decisions that shape their lives, of providing human beings with the opportunity to develop their future potential and of enabling the poor, women and free independent peasants to organise themselves and work together. Simultaneously, development is defined as a means to 
carry out a nation's development goals and to promote economic growth and national selfreliance."

Mazibuko (1996:150) agrees that the essence of developmental social welfare policies is helping solve problems, creating opportunities, providing access to resources and allocating resources, promoting natural helping and support networks, and enhancing people's capacities. Participation by civil society is imperative if development is to be empowering and sustainable. In South Africa there is a move away from a model of handouts and creating dependency on the welfare system to one where people take responsibility for themselves and which is empowering. According to Mbatha (1998:4), the word "empowerment" has been used to imply the promotion of community development through self-help, with an emphasis on the process rather than on the completion of participation projects. It also refers to the process of collective decision-making, collective action and popular participation. The empowerment process fosters self-reliance and the participation of the people in problem solving, which is fundamental to developmental welfare.

Internationally there has also been a move to sustainable people-centred development. Peoplecentred development moves away from centralised control to regional and local democratisation. The emphasis is on a move away from local government to local governance.

Roodt's (2001:469) definition of participation will be used in this article; it entails that people involve themselves, to a greater or lesser degree, in organisations indirectly or directly concerned with the decision making about, and the implementation, of development. This definition will be adopted here as most social work is implemented through non-governmental and state organisations.

\section{IMPORTANCE OF CIVIL SOCIETY PARTICIPATION AND ITS RELEVANCE TO SOCIAL WORK}

The participation of civil society is crucial if developmental social welfare goals are to be achieved. South Africa is going through a process of social transformation. An equitable distribution of power and resources and increasing democratisation and political freedom are two indices of social transformation (Pretorius-Heuchert \& Ahmed, 2001:32). Social transformation is contingent on transforming unequal power relations in society. Many African social workers (Ntebe, 1994; Mwansa cited in Osei-Hwedie, 1993) have reiterated the need for social workers to become involved in issues that promote equity and social justice. They are followers of the radical school of social work and are of the opinion that there have to be structural changes in society to uproot poverty and improve the welfare of its people. The central element of a radical approach places the emphasis on the desire for the disadvantaged to work collectively towards changing alienating conditions. It also stresses self-reliance and popular participation aimed at enhancing people's capacity to work for their own welfare (Anderson \& Wilson, 1994:77). Social workers have to be consistent and persistent in their roles as enablers, facilitators and advocates in their struggle for a humane welfare society (Ntebe, 1994:42).

One way of achieving equity is where ordinary citizens have access to and participate in locally constituted voluntary organisations (Swilling cited in Singh, 1993:2).

As a consequence of participation, significant structural transformation can take place at the community level; that is, social system learning (social system change and development) takes place when learning (experience acquired by individuals in a system) is achieved through problem-solving situations involving social actions. In other words, real change in social systems comes about as a result of real-life experiences involving problem-solving situations in which individual members within the system work together towards the fulfilment of system goals and 
objectives (Dunn cited in Abatena, 1995:16). The very fact of participation transforms the participating people's awareness of who they are, i.e. their consciousness, and enables oppressed people to take control of their lives (Freire cited in Hope \& Timmel, 1984:17).

Ukpong (1993:5) agrees that through participation in non-governmental organisations local people are assisted to build counter-prevailing power structures, acquire bargaining and leadership skills and provide enabling resources with which to sustain local initiatives, thereby enjoying a degree of autonomy in rural development.

Abatena (1995:15) views participation in community self-help activities as being instrumental in mobilising available community resources such as talents and skills, leadership, human energy, and capital and material resources. He further states that local self-help activities facilitate:

- $\quad$ co-operative and collaborative undertakings and the development of team spirit;

- $\quad$ joint decision-making and responsibility;

- $\quad$ effective mobilisation of community efforts and community resources;

- $\quad$ acquisition of better organisational and management skills;

- $\quad$ development of leadership skills; and

- $\quad$ development of an ability to initiate and accomplish a task.

An important value of social work is the protection of democracy, that is the sharing of control of society by all its people (Potgieter, 1998:41). An active and vibrant civil society is essential in protecting the interests of communities; it enriches and deepens the practice of democracy and acts as a watchdog on government. In the past non-governmental organisations played an instrumental role in the struggle for democracy.

Participation in community affairs can also forge national and civic unity out of a fractured and divided South African population. Phiyega (1990:6) asserts that social work agencies have a role to play in violence-torn communities and the task of the social worker is to re-establish family and other small groups to which people can relate and belong. Marias (1998:109) is also of the opinion that the high rate of crime is related to the lack of social cohesiveness and that the family structure, churches and community bodies have declined and disintegrated. Therefore the involvement of civil society in the South African debate could foster solidarity, communitarian values and an associational ethos that leads citizens to achieve social goals together (Singh, 1993:2).

Buckland (1998:236) is of the opinion that there is a need to mobilise indigenous social and political capital that would build or rebuild community capacity and ensure sustainability of impact. He believes that the notion of social capital, measuring the levels of norms of reciprocity and networks in a society, is helpful in understanding how to achieve participation, empowerment and re-establishing indigenous sustainable organisations and institutions. He believes community empowerment occurs when new networks and norms of trust and reciprocity evolve in the face of national and global changes, and when they move beyond traditional kinship and ethnic groups to encompass all members within a spatial community.

The role of civil society involvement is also crucial because, if developmental work is imposed from outside, there will be no sustainable and human development. Participation is important in that it ensures that development projects are oriented towards producing outcomes that meet the felt needs of the community. When developmental projects increase local levels of social capital, 
communities develop the capacity to help themselves. Communities that have helped plan, design and construct a project or asset are more likely to use and maintain it.

The involvement of civil society can also be cost effective. The government is clear that it cannot accept sole responsibility for redressing past imbalances and meeting basic physical, economic and psychosocial needs. Welfare systems are under threat throughout the world and therefore mobilisation of communities is being promoted (Bloch, 1996:129).

Civil society participation should be high on our agenda if true development is to be achieved. It has many benefits in ensuring equity, empowerment and sustainable development: all components relevant to social work.

\section{IMPLICATIONS FOR SOCIAL WORK PRACTICE}

Developmental interventions require a new way of working in partnerships with communities. Empowering of communities through participation remains a major challenge facing social workers. The aim of social work is getting "people to help themselves." Justice, equity and participation are integral social work values. However, we need to have to use our teachings and practice to find ways to organise and test indigenous practice models for restoring our communities to more productive functioning and fulfil the needs of its members. Pertinent issues for enhancing the participation of civil society relevant to social work practice will be discussed.

\section{Assessment of communities}

An understanding of civil society and communities is essential if social workers are to facilitate participation. There is a need for context specific participatory developmental interventions.

Social workers need to adopt a strengths-based approach when facilitating participation. They need to understand that oppressed people originally made up communities and they have the power, capacity and right to search for and recreate more perfect forms for well being continually (Pantola \& Perry, 1992:228). In the past many self-help groups, rural development forums, residence organisations, stokvels and burial societies emerged to cater for the survival of communities. Knowledge of these past organisations, strategies, strengths and limitations would be valuable in developing indigenous practice models. Through a process of education and reflection people may come to know that they possess strength, knowledge and skills that they can access, value and utilise.

Organising approaches must be compatible with the customs and values of communities. Ways in which people participate in collective action can have their basis in traditions.

A cultural analysis of communities is important. Participation is often based on cultural values, for example ubuntu, love, peace, satyagraha. People who live in rural areas and urban communities function within kinship bonds and communal networks. Participation could also be based on distinct styles of response to ethnic group issues, for example, gender roles (James, 1997:4). These values and traditions can be used constructively by social workers.

Civil society encompasses contending power relations and group interests which can either advance or impede important issues that social workers deal with, such as poverty reduction and equity (Fowler as cited in Pieterse, 2001:65). Social workers need to take into consideration the particularities of local politics in South Africa, especially in rural areas (Roodt, 2001:478). In rural areas the influential powers of traditional leaders are crucial in shaping the identity of local organisations and the nature of developmental processes. There is a need to understand the role of 
traditional leadership and the influence it could have on its followers. Social workers need to understand these dynamics and engage these actors.

It is also important that social workers recognise that communities often reflect divisions and competing interests and not necessarily harmony. One of the aims of participation is to promote solidarity in communities. The social worker has to be able to handle and assess group dynamics and focus on relationships in communities. Also, there is a need to understand why people don't participate. According to Roodt (2001:478), the achievement of general participation is difficult because local elites monopolise power and are often hostile to widespread participation. They use a combination of power positions, such as class, race, gender, age and education, often backed up by "tradition", to prevent participation. To deal with these issues social workers will needs skills in community power analysis, organising and conflict resolution (Lee, 1992:150).

\section{Human resource development and education}

As discussed earlier, participation of people in civic issues is an important way of promoting human resource development. In South Africa there are deprived and under-developed communities; their members generally lack the education, sense of civil belonging, participation and ability to take on civic responsibilities, as they have previously been excluded from the political process (Ntsime, 2001:116). It will take time and money to build a society where ordinary people have the sophistication and confidence required to influence power structures. The change effort of the social worker should focus on individual work and on the larger social system and structures. Traditional methods such as enhancing people's self-esteem will be important. Potgieter (1998:41) proposes that the strategy to achieve equity and social justice is to develop life-skills to empower people. In Africa this would include assisting disadvantaged people to develop the necessary skills to participate in national debates, organise for social justice, and demonstrate and agitate on behalf of themselves (Anderson \& Wilson, 1994:77). It is important to equip current community leaders and volunteers with knowledge and skills in community organisation. Providing relevant quality training is taken to be part of empowerment.

Volunteer mobilisation is an important way to get people to participate. The role of the social worker should include recruiting, training, mentoring and on-going supervision of volunteers.

Building the capacity of leaders in society is imperative. Leadership development is a process of influence between the leaders and the followers in the community. Important skills for leaders involve goal setting, programme planning, resource organising and strategic functioning. Another important skill for leaders is co-ordinating various human talents and social resources for effecting positive changes (Lee, 1992:151). Nurturing talent and developing skills in leadership is important. Young people could be an important target of social work intervention.

In the new context organisations are finding that they are having to play new roles which require different skills such as understanding development, restructuring organisations to be more efficient, effective and to deliver more appropriate services within a developmental framework (Patel, 1998:115). It is important that education and support should be given in this area so that people gain the confidence to participate and not become overwhelmed. Opportunities must be provided for local people to make management-level decisions about projects. Taken together this can give new skills to development. It is important that organisational structures do not deter citizens from participation. Smith (1996:197) is of the opinion that the heavy emphasis on formal management processes has been to deter volunteers from marginalised groups from coming forward. He further states that the challenge for organisations is to devise styles of management 
that support the needs of all volunteers and not just $10 \%$ of knowledgeable citizens. Organisational structures must be consistent with an African worldview.

Molefe (1996:25) believes that the essential prerequisite for participation in South Africa is conscientisation, which he defines as "...a process through which people achieve awareness of socioeconomic, cultural and political realities which shape their lives". In his view, conscientisation amounts to the creation of the will to change, which is an essential ingredient of community involvement, because if the will to change is absent, it will not be possible to involve the community meaningfully. Non-formal/social education are important techniques of social work and have a part to play in the process of the consciousness-raising of the poor. Social action is a way of making the poor conscious of their collective strength and aware of the role of various institutions that are designed for their welfare and development.

It is important that the social worker understand the motivation of participants in civic affairs. A reward system must be designed to render public recognition to those who have made a good contribution to the community (Lee, 1992:153).

In conclusion, the participation of civil society in development is imperative. It has many benefits for democracy and is relevant to social work. The paper has suggested ideas and challenges for social work practice in South Africa. Many of these ideas are not new to social work; however, they need to be tested, refined and expanded to meet the needs of our society.

\section{REFERENCES}

ABATENA, H 1995. The significance of community self-help activities in promoting social development. Journal of Social Development in Africa, 10(1):5-24.

AFRICAN NATIONAL CONGRESS 1994. The reconstruction and development programme. Johannesburg: Umanyano Publications.

ANDERSON, SC \& WILSON, MK 1994. Empowerment and social work education and practice in South Africa. Journal of Social Development in Africa, 9(2):71-86.

BLOCH, G 1996. Government outreach/dealing with the politics of development. NGO Week Conference Report, 122-125.

BUCKLAND, J 1998. Social capital and sustainability of NGOs intermediated development projects in Bangladesh. Community Development Journal, 33(3):236-248.

COWEN, M \& SHENTON, R 1995. The invention of development. In: CRUSH, J (ed) Power of development. London: Routledge.

HOPE, A \& TIMMEL S 1984. Training for transformation: A handbook for community workers. Zimbabwe: Mambo Press.

JAMES, R 1997. Organisation development and NGO's in Africa cross-cultural imperialism or effective developmental tool. OD Debate, 97:3-6.

JAMES, W \& CALIGUIRE, D 1996. The new South Africa: Renewing civil society. Journal of Democracy, 7(1):56-66.

LEE, IC 1992. The Chinese Americans-community organizing strategies and tactics. In: RIVERA, FG \& ERLICH, JL (eds) Community organizing in a diverse society. Boston: Allyn \& Bacon.

MARAIS, H 1998. South Africa limits to change. The political economy of transformation. Cape Town: Zed Books Ltd. 
MAZIBUKO, FNM 1996. Social workers and social policy: Related functions and skills in practice. Social Work/Maatskaplike Werk, 32(2):148-161.

MBATHA, MTS 1998. Confronting the challenges of community development and poverty alleviation in South Africa. Paper delivered at Workshop, "Developing Policy Practice Models For Poverty Alleviation" hosted by Provincial Department of Welfare and Population Development, KZN.

MOLEFE, SP 1996. Rural development in South Africa: Implications for social work practice. Journal of Social Development in Africa, 11(2):21-31.

MWANSA, LK 1995. Participation of non-governmental organisations in the social development process in Africa: Implications. Journal of Social Development in Africa, 10(1):65-75.

NTEBE, A 1994. Effective intervention roles of South African social workers in an appropriate, relevant and progressive social welfare model. Journal of Social Development in Africa, 9(1):41-50.

NTSIME, M 2001. Partnerships with civil society in the community based public works programme. Development Update, 3(4):113-127.

OSEI-HWEDIE, K 1993. The challenge of social work in Africa: Starting the indigenisation process. Journal of Social Development in Africa, 8(1):19-30.

PANTOJA, A \& PERRY, W 1992. Community development and restoration: A perspective. In: RIVERA, FG \& ERLICH, JL (eds) Community organizing in a diverse society. Boston: Allyn \& Bacon.

PATEL, L 1998. NGO's and service delivery challenges. Social Work/Maatskaplike Werk, 34(1):112-123.

PHIYEGA, MV 1990. The role of a child welfare organisation in strife-torn communities. Social Work Practice, 3(90):6-8.

POTGIETER, H 1998. The social work process: Development to empower people. Johannesburg: Prentice Hall.

PRETORIUS-HEUCHERT, JW\& AHMED, R 2001. Community psychology: Past, present, and future. In: SEEDAT, M \& DUNCAN, N (eds) Community psychology theory, method and practice: South African and other perspectives. Cape Town: Oxford University Press.

ROODT, M 2001. Participation, civil society, and development. In: COETZEE, JK; GRAAF, J; HENDRICKS, F \& WOOD, G (eds) Development Theory, Policy and Practice. Cape town: Oxford University Press Southern Africa.

SINGH, M 1993. The role of civil society in promoting democratic development: Some aspects of the South African debate. In: MICOU, AM \& LINDSNAES, B (eds) The role of voluntary organisations in emerging democracy. Denmark: The Danish Centre For Human Rights.

UPKONG, EA 1993. The constraints of NGO's operational flaws on rural development initiatives in Nigeria. Journal of Social Development in Africa, 8(1):51-72.

REPUBLIC OF SOUTH AFRICA 1996. Constitution of the Republic of South Africa. Government Gazette, No. 108. Pretoria: Government Printer. 